\title{
Forecasting Performance Of Natural Gas Futures Market: An Assessment Of Recent Data
}

\author{
Salah Abosedra, Lebanese American University, Lebanon. \\ Khaled Elkhal, University of Southern Indiana \\ Faisal Al-Khateeb, United Arab Emirates University, UAE
}

\begin{abstract}
Natural gas has assumed increasing importance in the global energy market. This study evaluates the forecasting performance of futures prices of natural gas in the large market of the U.S. at various time horizons. The results indicate that futures prices are unbiased predictors at the 1-, 6-, and 12- month horizons, but not at the 3- and 9- month horizons. The results further suggest that futures prices of natural gas, although biased at some intervals, significantly outperform naïve forecasts in predicting future movements of spot prices. In addition, the information content of the 1-month ahead futures price proves especially useful as a forecasting device. Policy implications are also discussed.
\end{abstract}

\section{INTRODUCTION}

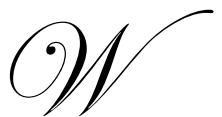

hile several studies examine the efficiency of crude oil futures markets in the U.S. and other consuming nations ${ }^{1}$, research on the efficiency of natural gas futures market in the U.S. and elsewhere is relatively scant. This appears surprising given the increasing importance of natural gas futures markets since its inception in 1990. Natural gas is a critical world commodity whose world consumption is expected to grow by $70 \%$ in the next two decades (International Energy Outlook, 2004). Its expected growth rate of more than $2.2 \%$ annually until 2025 is significantly higher than that of oil (1.9\%) and coal (1.6\%). The volume of futures natural gas contracts traded on the New York Mercantile Exchange (NYMEX) has more than doubled between 1999 and 2002. In addition, the extreme spikes in natural gas prices during 2000-2001, and the significant price increase since then, have made forecasting future prices a necessity for both producers and users of natural gas.

This study evaluates whether futures prices of U.S. natural gas provide unbiased and accurate forecasts of subsequent spot prices as is implied by market efficiency. In particular, we examine the forecasting performance of the 1-, 3-, 6-, 9-, and 12-month ahead futures prices of natural gas from November 1993 to November 2004. We investigate the predictive information content of futures prices using comparable forecasts from a naive forecasting model.

The rest of the paper is organized as follows. Section 2 provides a brief account of the relevant literature. Section 3 describes the data and the testing procedures. Section 4 discusses the empirical results. Section 5 concludes.

\section{PRIOR RESEARCH}

The issue of futures markets efficiency has received considerable attention in the literature since efficient futures markets provide investors with an important vehicle for risk reduction. Participants in the spot market can hedge unexpected changes in spot prices by participating simultaneously in the futures markets. This requires hedgers to calculate the optimal hedge ratio and sell an amount of futures contracts equal to this ratio for each spot position

\footnotetext{
${ }^{1}$ See, for example, Quan (1992) and Gulen (1998).
} 
they held. Early studies like Myers and Thompson (1989) calculate the optimal hedge ratio from regressing the returns to holding spot on the returns to holding the hedging instruments. Algebraically:

$s_{t}-s_{t-1}=\alpha+\beta\left(F_{t}-F_{t-1}\right)+e_{t}$

where, $s_{t}=$ spot price, and $F_{t}=$ price of hedging instrument.

Investors can reduce risk by acquiring an opposite futures' position relative to their spot position. Speculators are often interested in the efficiency of futures markets since they capitalize on arbitrage opportunities whenever short-run positions depart from long-run equilibrium conditions. Clearly, a sufficient difference between futures and spot prices is needed considering the associated cost of carry.

Herbert (1993) examines the relation between the settlement price of natural gas (NG) on the futures contract and the average spot price at the Henry Hub for the same delivery month. His evidence for the then young futures markets suggests possible market inefficiency. However, Walls (1995) reports contradictory results that are supportive of market efficiency. A more recent study by Murry and Zhu (2002) examines the efficiency of U.S. cash and futures natural gas markets in relation to the introduction in November 1999 of Enron Online (EOL) facilitated gas trading system. From November 1999 until Enron failed in late 2001, trading volume witnessed substantial growth, reaching more than $\$ 550$ billion in the first half of 2001 compared to only $\$ 50$ billion during the first half of 2000 . However, Murry and Zhu find no evidence for efficiency improvement associated with the EOL system, although they document significant increase in market volatility at the time of Enron collapse.

\section{DATA AND THE TESTING MODEL}

We use monthly spot and futures prices from November 1993 to November 2004. Spot prices represent closing prices observed in the last trading day of the month, while futures prices represent $f$-month ahead contracts observed at the close of the last trading day of the month with $f=1,3,6,9$, and 12 . We obtain Henry Hub spot prices from the Energy Information Administration and collect data on futures prices from the New York Mercantile Exchange (NYME).

Examination of information efficiency in the NG futures market is based on studying the short-term relationship between spot and futures prices. Some prior studies, e.g., Walls (1995), test market efficiency by exploring the long-run dynamics of the spot and futures relationship in the context of cointegration and errorcorrection models, though Brenner and Kroner (1995) argue that cointegration between spot and futures prices requires specific conditions that are unlikely to be satisfied in commodity markets.

Let $S_{t}$ and $P F_{t+f}$ be the logarithm of the spot price in month $t$, and the logarithm of the $f$-month ahead futures price made in month $t$, respectively. Let $P N_{t+f}$, be naive forecasts of NG prices for the different time horizons where $f$ stands for the corresponding monthly horizon. These forecasts are simply the logarithms of NG spot prices observed before the last trading day of the corresponding month $t$. Such prices could serve as naïve predictors of the future direction of natural gas spot prices since they represent the most recently known price information on the last trading day of the month when futures prices are determined.

We compare the forecasting performance of futures prices relative to those obtained from a naïve (and hence most likely inefficient) forecasting model. Futures prices are deemed inefficient if they are outperformed by naïve forecasts. We begin by testing unbaisedness of futures and naïve prices since it is a prerequisite for testing forecasting accuracy. To do that, we regress the $f$-month ahead spot price at time $t$, denoted by $S_{t+f}$, on the corresponding $f$ month ahead predictor of the spot price, also made at time $t$, and denoted by $P_{t+f}$. Algebraically:

$$
S_{t+f}-S_{t-1}=a_{0}+a_{1}\left(P_{t+f}-S_{t-1}\right)+v_{t+f}
$$


where $f=1,3,6,9$, and 12 and $v_{t+f}$ is a white noise error term. Note that the predictor variable $P_{t+f}$ could either be the naïve price or the futures price. We subtract the term $S_{t-1}$ from both sides of the above equation to ensure stationarity of the two variables (Fair and Shiller, 1990). Unbiasedness requires that $a_{0}=0$ and $a_{1}=1$ in equation (2) above.

The forecasting accuracy of futures prices $P F_{t+f}$ versus naïve prices $P N_{t+f}$ can be tested through estimating the following equation:

$S_{t+f}-S_{t-1}=b_{0}+b_{1}\left(P F_{t+f}-S_{t-1}\right)+b_{2}\left(P N_{t+f}-S_{t-1}\right)+v_{t+f}$

where $f=1,3,6,9$, and 12 and $v_{t+f}$ is a white noise error term. If $b_{1}$ is insignificant but $b_{2}$ is significant, then naïve prices outperform futures prices for predicting subsequent movements in spot prices, perhaps implying that the NG futures market is inefficient. However, if $b_{1}$ is significant while $b_{2}$ is not, then futures prices have more predictive information than naïve forecasts and the NG futures market is considered efficient. The two coefficients may both prove insignificant (significant) in which case futures prices and naïve forecasts have little (sufficient) power for predicting subsequent spot prices.

\section{EMPIRICAL RESULTS}

Before proceeding further, two remarks are in order pertaining to the nature of spot and futures prices. First, as shown in Table 1, spot prices display more volatility (measured by standard deviation) than do futures prices across all horizons. This suggests that investors in the futures market view their counterparts in the spot market as merely noise traders. Therefore, they tend to be more conservative in their trading approach and do not take price shocks in the spot market very seriously. Second, visual inspection of futures and spot NG prices of alternative contracts over the estimation period (not shown here to save space) suggests that the shorter is the maturity of the futures contract, the better is the forecasting accuracy. The 1- month ahead futures prices, observed at time $t$, move particularly closer to actual spot prices observed at time $t+1$.

Prior to testing forecast unbiasedness on the basis of equation (2), we check the stationarity requirement of spot and futures prices using the Weighted Symmetric test, the Augmented Dickey-Fuller, and the Phillip-Perron tests. The use of different unit-root tests is prudent to ensure that inferences regarding the important issue of data nonstationarity are not driven by the particular test used. The results (available upon request) indicate that futures and spot prices are non-stationary in levels but they become stationary if converted to first differences. Thus, we should subtract the term $S_{t-1}$ from both sides of equations (2) and (3) to ensure stationarity of the variables. To ensure statistically consistent estimates, we use the AR1 procedure to eliminate any possible first-order autocorrelation in the estimated errors.

Estimated results reported in Table 2 for equations (1) and (2) suggest that futures prices are unbiased predictors of subsequent spot prices at 1-, 6-, and 12- month horizons. However, futures prices appear biased predictors at the 3-and 9- month horizons since the coefficient estimates are significantly different from unity. Perhaps more importantly, futures prices consistently outperform naïve forecasts in terms of forecasting accuracy in all forecasting horizons since the coefficient estimates for futures prices are significantly different from zero whereas the coefficient estimates for naïve prices are not. Further support for this verdict comes from the fact that the adjusted Rsquare is consistently higher for the futures price equations than for the naïve price equations.

To shed further light on the above comparison, we compute Theil's inequality coefficient (U) to evaluate the usefulness of futures prices over naïve forecasts for predicting subsequent movements in NG spot prices. Theil's inequality coefficient is a standardized root-mean-square-error (RMSE) which ranges between 0 and 1 . Smaller values suggest good predictions whereas larger values suggest poor predictions. Table 3 reports results from Theil's comparisons. As can be seen from the table, the $U$ coefficients for futures prices are consistently lower than those 
from naïve forecasts at every interval level, including the 12-month ahead horizon. This implies that futures prices serve as a better forecasting tool than does the naïve model across all time horizons. Moreover, the coefficient $U$ is the lowest for the 1-month ahead forecast and it is the highest for the 12-month ahead forecast, confirming our previous conjecture that forecasts of short-term contracts seem more accurate than those of longer term horizons.

\section{CONCLUSION}

This study investigates whether futures prices of U.S. natural gas are unbiased and efficient predictors of subsequent spot prices at various monthly horizons. Such an examination should be useful given the profound economic and financial implications of sharp movements in energy prices in recent years. If futures prices of natural gas account well for subsequent movements of NG spot prices, then policy makers and regulators can benefit from the informational content of futures prices. Otherwise, it is advisable for policy makers and regulators to seek alternative means to forecast spot prices of NG in the future. Local gas utilities, attempting to stabilize NG prices in the future, have hedged price uncertainty by using forward contracts. Since spot prices of NG have been exceptionally volatile since 2000, heavy reliance on forward contracts seems too risky and the use of futures NG contracts to hedge pricing risk is expected to increase. Compared to forward contracts, futures contracts have the advantages of lower risk and lower transaction costs.

Our results suggest that futures prices are unbiased predictors for the 1-, 6-, and 12- month horizons, but not for the 3- and 9- month horizons. The evidence also reveals that, while biased at certain horizons, futures prices outperform corresponding naïve forecasts across all forecasting horizons. In addition, results from Theil's inequality coefficients suggest that the 1 month-ahead contracts provide the best predictor of future spot prices. Although the evidence we find over the sample period from November 1993 to November 2004 supports the use of futures NG prices as a reliable forecasting device, we caution that uncertainty in the future demand due for example to volatile weather conditions and political instability in major NG producers in the Middle East and elsewhere could adversely impact the forecasting performance of futures NG prices. Therefore, policy makers and public utilities should not rely exclusively on any one device, including futures prices, to forecast future directions of NG prices.

\section{REFERENCES}

1. Brenner, R.J. and Kroner, K.F., 1995. Arbitrage, Cointegration, and Testing the Unbiasedness Hypothesis in Financial Markets Journal of Financial and Quantitative Analysis 30: 23-42.

2. Fair, R.C. and Shiller, R.J., 1990. Comparing Information in Forecasts from Econometric Models. American Economic Review 71: 375-389.

3. Gulen, S.G., 1998. Efficiency in the Crude Oil Futures Market. Journal of Energy Finance and Development 3: 13-21.

4. Herbert, J., 1993. The Relation of Monthly Spot to Futures Prices for Natural Gas. Energy 18: 11191124.

5. Myers, R.J. and S.R. Thompson, 1989. Generalized Optimal Hedge Ratio Estimation. American Journal of Agricultural Economics 71: 858-68.

6. Murry, D. and Zhu, Z., 2002. ENRONONLine And Efficiency in the U.S. Natural gas market. Paper presented at the annual meeting of the international association of energy economists, Vancouver, B.C., October 2002.

7. Quan, J., 1992. Two-Step Testing Procedure for Price Discovery Role of Futures Prices. The Journal of Futures Markets 12: 139-149.

8. Walls, W.D., 1995. An Econometric Analysis of the Market for Natural Gas Futures. Energy Journal 16: 71-83. 
Table 1: Descriptive Statistics of Monthly Natural Gas Spot and Futures Prices (November 1993 - November 2004)

\begin{tabular}{lcccccc}
\hline & $\mathrm{S}$ & $\mathrm{F} 1$ & $\mathrm{~F} 3$ & $\mathrm{~F} 6$ & $\mathrm{~F} 9$ & F12 \\
\hline Mean & 1.066 & 1.084 & 1.095 & 1.088 & 1.084 & 1.074 \\
Std. Dev. & 0.468 & 0.453 & 0.435 & 0.423 & 0.409 & 0.394 \\
Minimum & 0.135 & 0.303 & 0.353 & 0.437 & 0.548 & 0.558 \\
Maximum & 2.405 & 2.280 & 2.243 & 1.959 & 1.970 & 2.015 \\
Sum & 141.771 & 144.204 & 145.590 & 144.692 & 144.182 & 142.877 \\
Variance & 0.219 & 0.205 & 0.189 & 0.179 & 0.167 & 0.155 \\
Skewness & 0.511 & 0.585 & 0.586 & 0.538 & 0.580 & 0.587 \\
Kurtosis & -0.526 & -0.652 & -0.815 & -1.030 & -1.007 & -0.975 \\
\hline
\end{tabular}

Notes: $S$ is spot price; $F 1$ is one-month ahead futures price; $F 3$ is three-month ahead futures price; $F 6$ is six-month ahead futures price; $F 9$ is nine-month ahead futures price; and $F 12$ is twelve-month ahead futures price.

Table 2: Tests of Unbiasedness and Forecasting Performance of Futures Prices Versus Naïve Forecasts

\begin{tabular}{|c|c|c|c|c|c|c|}
\hline Dependent Variable & Constant & Futures & Naive & RHO & DW & Adj. $R^{2}$ \\
\hline \multirow{3}{*}{$\begin{array}{l}\text { 1-month ahead spot } \\
\text { price }\end{array}$} & $\begin{array}{l}-.0057 \\
(-.3057)\end{array}$ & $\begin{array}{c}.8634 \\
(1.4878)\end{array}$ & -- & $\begin{array}{c}.0910 \\
(.89519)\end{array}$ & 1.9595 & .4930 \\
\hline & $\begin{array}{c}.0042 \\
(.2715)\end{array}$ & -- & $\begin{array}{r}1.0617 \\
(0.4430)\end{array}$ & $\begin{array}{c}-.1269 \\
(-.9405)\end{array}$ & 2.0271 & .4637 \\
\hline & $\begin{array}{c}-.0035 \\
(-.2198) \\
\end{array}$ & $\begin{array}{c}.5902 * * \\
(2.9337)\end{array}$ & $\begin{array}{c}.4145 \\
(1.4703)\end{array}$ & $\begin{array}{c}-.0541 \\
(-.3563)\end{array}$ & 1.9909 & .4969 \\
\hline \multirow{3}{*}{$\begin{array}{l}\text { 3-month ahead spot } \\
\text { price }\end{array}$} & $\begin{array}{c}.0072 \\
(.1412)\end{array}$ & $\begin{array}{l}.7584 * * \\
(2.9991)\end{array}$ & -- & $\begin{array}{c}.6541 * * \\
(9.9419)\end{array}$ & 1.7904 & 6092 \\
\hline & $\begin{array}{l}.0251 \\
(.4647)\end{array}$ & -- & $\begin{array}{c}.5672 * * \\
(5.1804)\end{array}$ & $\begin{array}{c}.6357 * * \\
(9.3919)\end{array}$ & 1.7335 & .5177 \\
\hline & $\begin{array}{c}.0038 \\
(.0722)\end{array}$ & $\begin{array}{r}.9160 * * \\
(5.6624)\end{array}$ & $\begin{array}{c}-.1679 \\
(-1.1234)\end{array}$ & $\begin{array}{r}.6657 * * \\
(10.1730)\end{array}$ & 1.8098 & .6100 \\
\hline \multirow{3}{*}{$\begin{array}{l}\text { 6-month ahead spot } \\
\text { price }\end{array}$} & $\begin{array}{c}.0334 \\
(.4053)\end{array}$ & $\begin{array}{c}.8749 \\
(1.4945)\end{array}$ & -- & $\begin{array}{r}.7845^{* *} \\
(14.5800)\end{array}$ & 1.9547 & .7474 \\
\hline & $\begin{array}{c}.0473 \\
(.5125)\end{array}$ & -- & $\begin{array}{c}.5849 * * \\
(5.1468)\end{array}$ & $\begin{array}{r}.7793 * * \\
(14.3080)\end{array}$ & 1.7307 & .6668 \\
\hline & $\begin{array}{c}.0314 \\
(.3767)\end{array}$ & $\begin{array}{l}1.0345^{* *} \\
(6.4627)\end{array}$ & $\begin{array}{c}-.1566 \\
(-1.1671)\end{array}$ & $\begin{array}{r}.7887 * * \\
(14.7890)\end{array}$ & 1.9738 & .7489 \\
\hline \multirow{3}{*}{$\begin{array}{l}\text { 9-month ahead spot } \\
\text { price }\end{array}$} & $\begin{array}{c}.0474 \\
(.4149)\end{array}$ & $\begin{array}{c}.6486 * * \\
(4.0540)\end{array}$ & -- & $\begin{array}{r}8396 * * \\
(16.9890)\end{array}$ & 2.1113 & .7514 \\
\hline & $\begin{array}{c}.0545 \\
(.4188)\end{array}$ & -- & $\begin{array}{c}.4231 * * \\
(7.6346)\end{array}$ & $\begin{array}{r}.8487 * * \\
(17.7330)\end{array}$ & 1.9876 & .7115 \\
\hline & $\begin{array}{c}.1067 \\
(1.0073) \\
\end{array}$ & $\begin{array}{c}.7376 * * \\
(4.5277) \\
\end{array}$ & $\begin{array}{c}-.0897 \\
(-.6763) \\
\end{array}$ & $\begin{array}{r}.8209 * * \\
(16.5520)\end{array}$ & 2.1032 & .7646 \\
\hline \multirow{3}{*}{$\begin{array}{l}\text { 12-month ahead spot } \\
\text { price }\end{array}$} & $\begin{array}{c}.1024 \\
(.9437)\end{array}$ & $\begin{array}{c}.9417 \\
(0.6029)\end{array}$ & -- & $\begin{array}{r}.8182 * * \\
(15.7730)\end{array}$ & 1.9885 & .7935 \\
\hline & $\begin{array}{c}.1114 \\
(.8163)\end{array}$ & -- & $\begin{array}{c}.5357 * * \\
(5.1827)\end{array}$ & $\begin{array}{r}.8299 * * \\
(16.7170)\end{array}$ & 1.8312 & .7151 \\
\hline & $\begin{array}{c}.0978 \\
(.9358)\end{array}$ & $\begin{array}{l}1.4418 * * \\
(7.7746)\end{array}$ & $\begin{array}{c}-.4593 * * \\
(-3.1131)\end{array}$ & $\begin{array}{r}.8183 * * \\
(15.8580)\end{array}$ & 2.0197 & .8084 \\
\hline
\end{tabular}

Notes: The independent variable Futures is the $f$-month ahead futures price corresponding to the $f$-month ahead spot price. RHO is the serial correlation coefficient and DW is the Durbin-Watson statistic. The figures in parentheses are t-statistics. An $* *$ indicates statistical significance at the $5 \%$ level.

Table 3: Theil's Inequality Coefficients for Comparing the Forecasting Accuracy of Futures Prices versus Naïve

\begin{tabular}{lccccc}
\multicolumn{7}{c}{ Forecasting Prices } \\
\hline Futures Prices & 1-month & 3-month & 6-month & 9-month & 12-month \\
Naïve Prices & 0.083 & 0.117 & 0.145 & 0.166 & 0.178 \\
\hline Nit The & 0.085 & 0.127 & 0.165 & 0.191 & 0.214 \\
\hline
\end{tabular}

Notes: Theil's inequality coefficient ranges between 0 and 1. A value close to zero indicates accurate forecasts whereas a value close to one indicates inaccurate forecasts. 

NOTES 